Campbell K \& Tabner I (2014) Bonding and the agency risk premium: An analysis of migrations between the AIM and the Official List of the London Stock Exchange, Journal of International Financial Markets, Institutions and Money, 30 (1), pp. 1-20..

This is the peer reviewed version of this article

NOTICE: this is the author's version of a work that was accepted for publication in Journal of International Financial Markets, Institutions and Money resulting from the publishing process, such as peer review, editing, corrections, structural formatting, and other quality control mechanisms may not be reflected in this document. Changes may have been made to this work since it was submitted for publication. A definitive version was subsequently published in Journal of International Financial Markets, Institutions and Money, [VOL 30, ISS 1 (2014)] DOI: http://dx.doi.org/10.1016/j.intfin.2014.01.004 


\title{
Bonding and the agency risk premium: An analysis of migrations between the AIM and the Official List of the London Stock Exchange
}

\author{
Kevin Campbell and Isaac T. Tabner ${ }^{*}$ \\ Tuesday, 25 February 2014
}

\begin{abstract}
Firms that change their listing from the less regulated AIM to the more regulated main section of the London Stock Exchange exhibit positive abnormal returns on the announcement day. For firms moving in the opposite direction, both announcement and implementation day abnormal returns are negative. Following implementation, the pattern is reversed for both categories of firm. We show that differences in liquidity, conventional risk factors and in medium to long term firm survival rates between the two listing regimes do not explain the observed patterns of returns, suggesting that the answer lies in the different bonding requirements of the two market segments and an agency risk premium.
\end{abstract}

Keywords: Corporate Governance, Listing Change, Agency Costs, Agency Risk, Bonding Costs, Alternative Investment Market (AIM).

JEL Codes: G12, G14, G15, G30, G32, G34.

Contact details: Both Isaac Tabner and Kevin Campbell are at the Accounting and Finance Division, Stirling Management School, University of Stirling, Scotland, UK, FK9 4LA. Phone: 44 (0) 1786 - 467305, Fax: 44

(0) 1786 - 467308, E-mail: isaac.tabner@stir.ac.uk and: kevin.campbell@stir.ac.uk.

\section{Acknowledgements:}

The authors would like to thank the University of Stirling for funding this research; Leone McKinley for providing invaluable research assistance; the participants of the 2008 Scottish area conference of the British Accounting Association (11 ${ }^{\text {th }}$ September 2008); participants of the University of Stirling Accounting and Finance Seminar (19 ${ }^{\text {th }}$ November 2008); participants of the 7th International Conference on Corporate Governance: "Corporate Governance: Managing Risk in a Changing World", Birmingham Business School Monday, 29th June 2009, including Erik Theissen and Bastian Hinterramskogler for their valuable comments; participants at the $8^{\text {th }}$ National Taiwan University International Economics, Finance and Accounting Conference, $23^{\text {rd }}$ June 2010, including Wan-Jiun Paul Chiou and Hao-Chen Liu; an anonymous reviewer at the Journal of International Financial Markets, Institutions and Money, and also the editor G. Geoffrey Booth. Any remaining errors are the responsibility of the authors.

"Corresponding author. 


\section{Introduction}

Determining the level of corporate governance regulation that balances the costs of disclosure and compliance requirements with the benefits of a stock exchange listing is an important and challenging problem. The "bonding hypothesis" proposed by Coffee (1999) and Stulz (1999) suggests that firms can bond themselves to good corporate governance by listing on a foreign stock exchange with higher governance standards and thus constrain insiders from appropriating wealth from minority shareholders. Likewise, Skaife, Collins and LaFond (2004) demonstrate that a firm's corporate governance attributes influence both its systematic and non-systematic risk and, hence, its cost of capital, implying the existence of "agency risk" as an asset pricing variable.

Firm managers may mitigate agency risk by committing the firm to greater bonding, thus signalling to investors that agency costs will be easier to control. One way of doing this is to seek a listing on an exchange that requires greater bonding commitments: either by a cross listing, or by a migration. Motivations for cross listing have been examined in a number of studies (e.g. Hail and Leuz, 2009; Lel and Miller, 2008; Doige, Karolyi, and Stulz 2007; Pagano, Roell and Zechner, 2002; La Porta, Lopez-De-Silanes and Shleifer, 1999; Foerster and Karolyi, 1999; Amira and Muzere, 2011). The primary focus of these studies is firms that list on, or migrate to, a more regulated exchange, rather than on firms that migrate from a more to a less regulated exchange.

The present study falls into a related category of studies that examine migrations between different regulatory and governance regimes within the same geographic or legal jurisdiction (e.g. Leitterstorf, Nicoletti and Winkler, 2008; Jenkinson and Ramadorai 2013; Vismara, Paleari and Ritter, 2012). Specifically, we investigate migrations between two sections of the London Stock Exchange (LSE): the Official List (main section) and the smaller Alternative Investment Market (AIM). An advantage of focusing on firms that transfer between different tiers of the same market is that we automatically control for the 
legal protection afforded to shareholders and the stock exchange trading technology. A within-country study such as ours also reveals the ability of a stock exchange to influence the level of investor protection over and above that provided by existing law.

We define agency risk as the ex-ante uncertainty surrounding the nature and magnitude of agency costs. Unlike conventional risk factors such as market, size, style, momentum and liquidity, agency risk arises from the information asymmetry between agents who control information about the firm and outside investors (principals) who make capital allocation decisions. We argue that by its nature, such risk is firm specific and difficult to parameterise with a known probability distribution. Principals do not know ex-ante what, if any, information is being withheld by agents; in other words, they do not know what they do not know, so we conceive of this risk as Knightian uncertainty (Knight, 1985 [1921]). ${ }^{1}$ The entrepreneur earns a profit as the reward for bearing this uncertainty by agreeing predetermined contractual obligations with labourers and other resource suppliers in exchange for uncertain residual returns (Knight, 1985 [1921], pp 269 - 270). As an entrepreneur's business develops and a trading history emerges, the balance may shift from uncertainty towards insurable risk - where possible outcomes can be classified and subjective probabilities assigned to them - although uncertainty is never eliminated and the shift can be reversed (Knight, 1985 [1921], pp. 215 - 216). Firms listed on the AIM are typically early stage ventures, so we posit that agency risk will be greater than for firms listed on the Official List. Firms migrating between the two bonding regimes are subjected to a change in bonding obligations that directly causes a change to the level of agency risk faced by their investors: in the low bonding regime of the AIM, agency risk is higher, whereas in the high bonding regime of the Official List it is lower.

\footnotetext{
${ }^{1}$ We are grateful to an anonymous reviewer for guiding this characterisation of Knightian uncertainty.
} 
We argue that when agency risk increases, investors demand a premium on the cost of capital over and above that captured by standard models such as the CAPM or Fama and French (1993) model. We base this proposition on the grounds that agency risk is driven by firm specific characteristics rather than macro events and is not necessarily constrained by firm size, leverage or market to book ratios. In addition, the agency risk of individual firms is likely to persist over multi-year periods. However, we argue that a listing migration between the two segments of the London market triggers a change in the level of agency risk perceived by investors, given the different bonding requirements, which results in a change to the cost of capital to reflect the new agency risk premium. The dividend discount model implies that in the absence of changes in cash flows a change in the cost of capital will change firm value. Ceteris paribus, subsequent returns will reflect the new cost of capital. Thus, a unique contribution of our study is to examine the effect of changes in the level of agency risk on firm value and the cost of capital.

We test our hypothesis by studying returns surrounding the announcement and implementation of migrations between two sections of the LSE. Returns attributable to the agency risk premium are identified using a return generating model that, in addition to market, size and book to market risk factors, also controls for industry and liquidity risk. The latter is measured by the bid-ask-spread, which also controls for time variation in information asymmetry (Glosten and Milgrom, 1985). Though we cannot measure agency risk directly, as it is inherently unobservable, by including in our model the other possible explanatory variables identified in the asset pricing literature we are able to attribute the residual (abnormal) returns not explained by our model to the agency risk premium.

Our study makes five contributions to the literature. First, we draw attention to the role of agency risk in explaining the differential returns of firms in the two listing regimes. Second, we use daily returns as opposed to the weekly returns typically used in other studies, and a benchmark returns model that controls for industry residual returns and the possibility of an interaction between market risk and change of listing status. Third unlike other studies that 
compare migrations between market segments (for example, Baker and Edelman 1992a; Baker and Edelman 1992b; Bacmann, Dubois and Ertur 2002; Clyde, Schultz and Zaman 1997; Carvalho and Pennacchi 2012; Lamba and Arif 1997; Lamba and Khan 1999; Tse and Devos 2004; Leitterstorf, Nicoletti and Winkler 2008, Gerakos, Lang and Maffett 2013; Jenkinson and Ramadorai 2012; Vismara, Paleari and Ritter 2013), we control for both time and cross sectional variations in three proxies for liquidity: the bid ask spread, standardised trading volume and the free float ${ }^{2}$. Fourth, we empirically examine changes in risk and return resulting from changes in listing status. Fifth, complementing Espenlaub, Khurshed and Mohamed (2012) we find that while short term survival rates are somewhat higher for firms seeking promotion, the medium to long term survival rates are identical for both categories of firm. This suggests that differences in bankruptcy risk do not drive the observed return patterns, implying that differences in agency risk are responsible.

The rest of the paper is organized as follows. In section 2, we consider the UK institutional context with respect to the LSE and AIM. The theoretical background and hypotheses are detailed in section 3 , followed by a discussion of the data characteristics in section 4 . The results and conclusions are presented in sections 5 and 6 respectively.

\section{The London Stock Exchange and AIM}

Taken together the two sections of the LSE have characteristics which make them particularly suited to a study of the influence of the regulatory environment on the cost of capital. For example, although the main market of the LSE ranks highly in terms of the level of investor protection provided (La Porta, Lopez-De-Silanes, Shleifer, and Vishny, 1997; La Porta, Lopez-De-Silanes, Shleifer, and Vishny, 1998; La Porta, Lopez-De-Silanes, and Shleifer, 1999; Bebchuk, 2005; Bebchuk, 2007; Becht, Franks, and Rossi, 2009) the AIM section of the LSE is, arguably, one of the most lightly regulated markets in the developed

\footnotetext{
${ }^{2}$ While Lamba and Arif (1997) and Clyde, Schultz and Zaman (1997) do examine cumulative abnormal trading volume for listing promotions on the Japanese and US stock markets respectively, they only consider unidirectional switches.
} 
World. Additionally, more than twice as many firms transfer from the main market to the AIM as transfer in the other direction. It is unusual to see such a high number of firms seeking to migrate from a more regulated exchange to a less regulated exchange within the same jurisdiction. In fact, on many junior exchanges, it is either not possible for them to accept firms from their more senior counterparts, or else such an occurrence is considered exceptional. Firms listed on most multi-tier exchanges typically seek promotion to a more senior exchange, or, if delisting, seek a complete removal of their quotation.

The less stringent governance, reporting and listing requirements faced by AIM firms compared to the main market is a characteristic that, arguably, results in a higher cost of capital. Firms listed on the main market are subject to the "comply or explain" principle of the UK Corporate Governance Code, formerly known as the Combined Code (Financial Reporting Council, 2010). Although the efficacy of the "comply or explain" principle may be questioned (e.g. MacNeil and Li, 2006) AIM firms do not have to abide by it; instead they only have to apply the AIM Rules for Firms (London Stock Exchange, 2010). These contain provisions concerning the conduct of directors and the disclosure of remuneration and other information that are significantly less onerous than the UK Corporate Governance Code. Following the Enron scandal and the passage of the Sarbanes Oxley Act (SOX) in 2002, the cost of listing in the US increased relative to the London markets (among others) making London markets potentially more attractive locations for foreign firms. In fact, Piotroski and Srinivasan (2008) find that large foreign firms are no less likely to choose the US market over London, but smaller firms are more likely to consider a UK listing, and in particular an AIM listing over a US listing, post SOX. This suggests that for smaller firms, the lower cost of maintaining a listing on AIM potentially outweighs the higher cost of capital, including higher agency costs.

Although the UK Corporate Governance Code does not apply to AIM firms, shareholders are nevertheless provided with a safeguard in the form of a requirement for each company to have a Nominated Adviser or 'Nomad' approved by the LSE. Generally 
investment banks, accountancy firms or corporate finance advisory firms, they are responsible for advising on compliance with the AIM Rules for Firms (London Stock Exchange, 2010) and promoting good practice. For example, a company seeking to join AIM must appoint a Nomad to help the applicant come to the market. These rules also require Nomads to "consider, with the directors of an applicant, the adoption of appropriate corporate governance measures" (p. 17) and they state that Nomads must also be satisfied that a company has in place "sufficient systems, procedures and controls" (p. 18) to comply with the AIM Rules for Firms. Nomads must also comply with the AIM Rules for Nominated Advisers (London Stock Exchange, 2007a) which require them to contact the AIM regulation team if they believe that a firm for which they act is no longer appropriate for AIM (Rule 14, p. 8). The Nomad is thus central to the AIM's regulatory model, acting in effect as gatekeeper, adviser, and regulator. The possibility of facing disciplinary action for failing to properly assess a company's suitability for AIM, or for tolerating post-listing misdemeanours, should compel Nomads to perform their roles diligently. The AIM can thus be regarded as a "reputational market" in which investors rely on the character of Nomads as a proxy for the quality of listed firms, rather than on the market's regulations (Mendoza, 2008). However, the Nomad-client relationship is complicated by the fact that the Nomad is hired and paid for by the client, leading Gerakos, Lang and Maffett (2013) to characterise the system as "private regulation" [this is more or less repeated again on p. 12]. They also question the amount of oversight provided by Nomads in practice given that the requirements for admission as a Nomad are "quite light".

The LSE does not typically disclose Nomad censures for breaches of the AIM Rules for Nominated Advisers, preferring to deliver disciplinary action privately. However, three censures have been made public since the AIM launched in 1995, indicating that the LSE is holding Nomads to account but also suggesting that reliance on Nomads may give investors 
undue confidence in AIM firms. ${ }^{3}$ The first censure was disclosed in October 2007 when the Nomad Nabarro Wells was fined £250,000 (London Stock Exchange, 2007b). The LSE reviewed the conduct of Nabarro Wells during 2006, selecting seven AIM firms for which it acted as Nomad, and finding material breaches of AIM rules in respect of five of them. While exonerating the firms, it found that Nabarro Wells had acted without "due skill and care", had "failed to undertake the necessary level of due diligence to assess the appropriateness of certain firms for admission to AIM" including one "company's inability to raise the required funds on admission which was necessary to achieve the assumed growth projections included in its working capital report" (London Stock Exchange, 2007b, p. 4)

The second censure was published in June 2009 when the Nomad Blue Oar Securities (since renamed as Astaire Securities) was fined $£ 225,000$ for failing to question the accuracy of its client's announcements and to assess its ongoing suitability for an AIM listing (London Stock Exchange, 2009). Though not disclosed in the Disciplinary Notice, the client was identified in the press as the company Worthington Nicholls Group plc, whose business involves installing air conditioning and ventilation in hotels (Taylor, 2009). Among the announcements by Worthington Nicholls that Blue Oar knew were inaccurate or misleading, but failed to prevent, was a reference to a "high percentage of recurring revenue" when orders received had actually fallen from $£ 932,077$ to $£ 164,580$ (a decrease noted by Blue Oar in an email to the client) and a reference to discussions for potential deals with "five hotel chains, which, in aggregate, own in excess of 90 hotels" when in reality Worthington Nicholls was in contractual negotiations with just one hotel from each of the five chains (London Stock Exchange, 2009, p 7).

\footnotetext{
${ }^{3}$ The LSE has also censured and fined some AIM listed companies without taking action against their Nomads. For more details see Blackwell (2009), Mallin and Ow-Yong (2010) and Appendix II in Gerakos, Lang and Maffett (2013).
} 
The third case was disclosed in December 2011 when the disciplinary committee of AIM publicly censured the Nomad Seymour Pierce and imposed a record fine of $£ 400,000$ for breaches of four Nomad rules in relation to two client firms that occurred in 2010 (London Stock Exchange, 2011c). The LSE had conducted a routine visit to review Seymour Pierce's conduct as a nominated adviser in May 2010, as a result of which various concerns and recommendations had been raised about its standard of work. However, the LSE "did not initially receive from Seymour Pierce the level of co-operation it had expected or required in relation to the matters it had raised" (London Stock Exchange, 2011c, p 4). Further investigation then resulted in the public censure notice, which discloses that in one case Seymour Pierce failed to provide proper advice and guidance to a client in relation to the client's obligation to inform the market promptly of material changes in its financial situation. The client's share price rose by 80 per cent on news of a healthy order book, only for it to be placed into administration three weeks later, having failed to disclose that the directors had issued a short-term working capital loan to the company four weeks earlier. In the other case it failed to carry out proper due diligence on a client planning to list on AIM. The most troubling aspect of this censure is that at the time of its announcement Seymour Pierce was the largest Nomad on AIM, advising 74 firms.

The diligence with which Nomads perform their duties is questioned by Mallin and OwYong (2010). Based on interviews with two Nomads that advised more than 160 AIM firms, accounting for more than $10 \%$ of UK incorporated AIM firms at the time, they formed the impression that the brokering services also provided by these Nomads to their clients was "far more important" than their role as a Nomad, which they tended to view in a "passive capacity". The opinions of the 19 directors of AIM firms interviewed by Mallin and OwYong (2010) was mixed, with some indicating that their Nomad had been very supportive whilst others indicated that they had received little support. The general view formed by the authors from interviews with four institutional investors is that the Nomad is not a significant factor in the decision to invest in an AIM company. A survey of 20 institutional 
investors conducted in 2010 by Baker Tilly found that as many as $70 \%$ of them believed that further increases in regulation of the AIM market were required (Baker Tilly, 2011). The composition of the board of directors, in particular the presence and role of non-executive directors, was an area where some of these investors saw grounds for tightening of corporate governance requirements, with half of them judging the non-executive directors in AIM firms to be "not very effective".

Although the need to 'comply or explain' with the UK Corporate Governance Code is not obligatory for AIM firms, as a minimum they are encouraged by the LSE to follow the Corporate Governance Guidelines for Smaller Quoted Firms, produced by the Quoted Firms Alliance (QCA), a trade members' organisation whose work focuses on issues affecting small and mid-cap quoted firms outside the FTSE 350. These guidelines are based on the provisions of the UK Corporate Governance Code but are less prescriptive and detailed as they are tailored to the needs of smaller, growing firms. Irrespective of whether AIM firms adopt these basic rules from the QCA or opt for compliance with relevant aspects of the UK Corporate Governance Code, the QCA Guidelines recommend that a corporate governance statement is published each year, either in the annual report and accounts or on the website. At a minimum this statement should describe how each of the 12 guidelines for good practice contained in the QCA Guidelines is put into effect.

Like the UK Corporate Governance Code, the QCA Guidelines specify the need for independent non-executive directors, for separating the role of chairman and chief executive, for establishing remuneration and audit committees made up of non-executive directors, setting up a nomination committee to recommend board appointments, and establishing a dialogue with shareholders. However, the QCA Guidelines are generally less demanding: for example, a minimum of two independent non-executive directors are recommended by the QCA Guidelines, one of whom may be the Chairman if deemed independent at the time of appointment, whereas the UK Corporate Governance Code recommends that independent non-executive directors should comprise at least half the board, excluding the 
Chairman. ${ }^{4}$ In the absence of a mandatory requirement to adopt a particular corporate governance code, directors of an AIM company have a degree of flexibility and discretion in their approach to corporate governance. With guidance from their Nomad, AIM directors can put in place systems that balance the needs and resources of what is often a smaller, growing business against the need to have an effective governance system that will deliver transparency and trust between the board and the shareholders. However, if they fail to strike the right balance between the proportionality of governance systems and their effectiveness, they risk undermining shareholder confidence.

Over and above compliance (or otherwise) with corporate governance guidelines, AIM firms have to abide by the rules for admission to the market and thereafter comply with a number of continuing obligations to maintain their listing. In Europe, there are two legally defined ways to access the capital market: 'EU-regulated markets' and markets regulated by the stock exchanges themselves ('exchange regulated markets'). As the AIM is an 'exchange regulated market', the rules are set by the LSE and, as we have seen, are based on the company's relationship with its Nomad. In contrast, the main market of the LSE is an 'EU-regulated market' that requires firms to produce a full prospectus for approval by the UK Listing Authority (UKLA) and then to abide by the continuing obligations which apply to all admitted firms, such as ensuring that price sensitive information is made available to all investors at the same time. Both the admissions criteria and the continuing obligations are significantly less onerous for AIM firms than for main market firms (and our analysis of the published explanations for migrations in Table 1 indicates that 'cost savings, simplifications of reporting/regulation' is mentioned by a sizeable number of the firms moving down to the AIM). For example, whereas main market firms must have a three-year trading record and ensure a minimum of 25 per cent of the shares are in public hands after

\footnotetext{
${ }^{4}$ Though for smaller companies - i.e. those not included in the FTSE 350 throughout the year immediately prior to the reporting year - the UK Corporate Governance Code requires at least two independent nonexecutive directors.
} 
flotation, AIM firms require no trading record and there is no minimum free float. As a result many firms listed on the AIM have concentrated shareholdings. It is in fact possible to create a new company and have it listed on the AIM within two to three weeks, provided a Nomad can be found.

Insert Table 1 about here

There is considerable overlap in size between firms listed on the AIM and on the main market. For example, after excluding investment firms and firms with a market capitalization of less than $£ 1 \mathrm{~m}$, on 31 March 2011 there were 574 UK firms with ordinary shares listed on the main market: of these, $421(73 \%)$ had a market capitalization less than the $£ 1.39$ bn market capitalization of the largest firm listed on the AIM (London Stock Exchange 2011a). With no prescribed governance requirements in the AIM Rules for Firms, AIM firms may look to the main market's UK Corporate Governance Code for guidance on key aspects of governance. However, Snell and O'Brien (2008) find that whilst $77 \%$ of the Top 100 AIM firms by size comply with some aspects of this Code, only $3 \%$ choose to fully adopt it.

Board composition is an area where many AIM firms are weak when benchmarked against the UK Corporate Governance Code, which requires that boards have a balance of executive and non-executive directors. Only half of medium sized AIM firms (with a market capitalisation between $£ 40$ million and $£ 100$ million) that were sampled by Snell and O'Brien (2008) were found to have a majority of non-executive directors on their board, though this rose to $71 \%$ for the Top 100 . This is important given evidence that shareholder wealth increases when the proportion of outside directors increases (eg Rosenstein and Wyatt, 1990). Whereas the UK Corporate Governance Code requires firms to separate the roles of Board Chairman and CEO, up to $45 \%$ of AIM firms were found to combine these roles (Snell and O'Brien, 2008). So doing creates a conflict of interest which has been found 
to reduce firm performance, increase CEO compensation and reduce the sensitivity of CEO turnover to firm performance (Core, Holthausen and Larcker, 1999; Goyal and Park, 2002).

Many AIM firms have never made a profit and can be characterized as pure plays on a particular technology or business plan. As a result, they may be perceived as riskier than firms listed on the main market, which generally have a longer trading history, a more demonstrable record of profitability and a higher free float. When AIM firms are able to demonstrate a sustainable record of profitability and a market capitalization exceeding $£ 500$ m they are encouraged by the LSE to transfer their listing to the main market, but this is not obligatory (Arcot, Black, and Owen, 2007, p. 39). In fact, we find that more than twice as many firms move from the main market to the AIM than move in the opposite direction, while the overlap in size between firms on both exchanges suggests that many firms choose not to seek promotion, even if they meet the criteria. Overall the listing migrations comprise transactions that are economically significant: the total value of firms moving up to the Official List over the study period from January 1996 through February 2011 was $£ 22.3$ bn while the corresponding figure for firms moving down to the AIM was $£ 4.8 \mathrm{bn}$.

Although some firms on the main market may be tempted to move to the AIM to take advantage of its less prescriptive regime ("regulatory arbitrage") the LSE expect both nomads and institutional investors to ensure that firms raise their corporate governance standards as they increase in size (Arcot, Black and Owen, 2007, p. 23). However, investigations of corporate governance disclosure among AIM firms have uncovered a variety of corporate governance practices, with larger AIM firms not necessarily providing better governance (Mallin and Ow-Yong, 1998, 2008; Snell and O'Brien, 2008). Notwithstanding the AIM rules for Firms and the UK Listing Authority (UKLA) rules, our findings indicate that firms often provide very little notice or justification for a listing change and shareholders are often not given the opportunity to vote for, or against, the change. 
In their comparison of the AIM with the NASDAQ and OTC Bulletin Board (OTCBB) in the US and the LSE Main Market in the UK, covering the period June 27th 1995 to December 31st 2008, Gerakos, Lang and Maffett (2013) find that AIM firms produce lower returns, have lower liquidity and are significantly more likely to fail. The authors highlight the AIM's more relaxed regulatory environment and characterise it as "much more like a landing pad for struggling firms than a launching pad for highfliers" (p. 24). The regulatory environment in which AIM firms operate thus poses greater agency risks for investors, so firms that use the AIM as a launching pad for the LSE are willing to incur greater regulatory costs to bond themselves to investors when they migrate upwards, while those LSE firms using the AIM as a landing pad are trading off greater agency costs against the reduced burden of regulation and disclosure when they migrate downwards.

The possibility that the lower standard of regulation on the AIM attracts lower quality firms that are unable to list in more regulated markets was investigated by Nielsson (2012). His results show that firms listed on AIM, although smaller in size, are equivalent in terms of profitability, growth and leverage to firms listed in the NYSE and NASDAQ exchanges in the U.S. and in two Continental European exchanges (the Deutsche Börse and Euronext). He also demonstrates that the delisting pattern is the same across these markets and concludes that the AIM does not cater to lower quality firms.

As well as sending signals about future agency costs and firm performance, a decision to transfer a listing may have tax consequences for UK residents investing in main market and AIM firms. This is because, unlike firms listed on the AIM, firms on the main market are eligible for inclusion in an Individual Savings Accounts (ISA). An ISA is a tax shelter available as an annual allowance for individuals resident in the UK. For example, in the fiscal year 2013/14 an individual could pay up to $£ 11,520$ into a stocks and shares ISA, although this limit was considerably less at the beginning of the study period. Gains realised on investments held in ISAs are free of capital gains tax and dividends are taxed at the basic rate regardless of the tax bracket of the investor. Although not eligible for inclusion within 
an ISA investors in AIM firms enjoyed other generous tax benefits during the study period that were not available to investors in main market firms. These stem from a decision implemented in 2000 to treat firms listed on AIM as unquoted firms for tax purposes, producing benefits which include entrepreneurs' relief against capital gains tax (CGT), enterprise investment scheme tax relief and inheritance tax business property relief, though these benefits were less valuable after 2008 due to changes in the UK tax code. The existence of these multiple incentives suggests that the tax motivation is likely to be more powerful for firms migrating down to the AIM, and this is borne out in the information provided in Table 1 where the stated motivation of achieving 'tax benefits to investors' is not mentioned by any firms moving up to the main market but is mentioned by 34 firms migrating down to the AIM.

Relief against capital gains for investors moving down to the AIM is, however, only beneficial if investors are liable to CGT and is of no value for tax-exempt investors such as pension funds. The value of relief against inheritance tax depends upon whether individual investors foresee themselves as being liable to this tax, and even for such investors there are other well-established ways to reduce any potential liability. Further, the tax benefits of AIM investments are only of value to individuals who are subject to UK taxation. Though firms that switch their listing without providing adequate warning may trigger forced sales by investors with unforeseen tax liabilities, given the tax planning opportunities available to individuals to reduce the impact of such liabilities, and given that the AIM investor base comprises mainly institutional investors (Mendoza, 2008), we believe that any tax impact is likely to be negligible. Nevertheless, as one of our robustness checks we control for liquidity changes around listing migrations to take account of any unusual trading activity that might occur. 


\section{Theoretical background and hypotheses}

Firms may change their listing, or list on more than one exchange, when the group of investors with the greatest comparative advantage in assessing their value are based on a foreign exchange (the "investor recognition hypothesis" of Merton (1987)). Alternatively, a listing change may occur when a foreign exchange has a higher listing standard, thus allowing the firm to signal to potential investors that it is prepared to subject itself to higher standards of disclosure and corporate governance, thereby justifying a lower cost of capital (the "bonding hypothesis", e.g. Coffee (1999)). A further possibility is that firms may change their listing when analyst coverage and the pool of potential investors is larger on another (usually foreign) exchange, resulting in greater liquidity and lower transaction costs (respectively, the "liquidity hypothesis" of Amihud and Mendelson (1986) and the "market segmentation" hypothesis of Kadlec and McConnell (1994)).

Competing exchanges can either "race to the top" or "race to the bottom" when setting their listing requirements. Indeed regulatory arbitrage can work both ways as firms may "race to the top" in seeking listings on exchanges with more stringent corporate governance standards than found in their home country (Coffee 1999; Piotroski and Srinavasan 2008 and Pagano et al. 2002). In fact, Chemmanur and Fulghieri (2006, p. 458) argue that "high reputation" exchanges are likely to reinforce their comparative advantage by setting high listing standards, while "low reputation" exchanges will set lower standards and become lower-tier markets.

It is also probable that firms with concentrated ownership are inclined to avoid listing on exchanges where greater rights are afforded to minority shareholders Coffee (1999, p. 703). According to this reasoning the AIM is likely to be favoured over the main market by firms with concentrated ownership not least due to the absence of free float restrictions on AIM firms. 
The decision to alter listing status may also be influenced by the additional financial disclosures required on a more regulated exchange as these serve to bond a firm's managers to its shareholders and thus reduce agency risk. However, smaller firms may have less wish to incur additional bonding costs. Likewise firms with controlling shareholders may not regard an increase in bonding costs to be worth the resulting reduction in agency risk. If increased bonding costs incurred by firms graduating to the main market are outweighed by a lower cost of capital, asset pricing theory suggests that their stock prices should rise and subsequent expected returns should fall on the announcement of such a switch. This is because the risk premium declines to reflect the lower agency risk as investors' uncertainty regarding the magnitude of agency costs is moderated due to an official listing. This leads to our first hypothesis:

Hypothesis 1. Firm value will increase immediately following the announcement and transfer of firms from the AIM to the main market, followed by subsequent lower returns.

On the other hand, firms transferring down from the main market to the AIM might be expected to initially suffer a stock price fall, but eventually the additional risk premium required to compensate for the higher agency risk of the less regulated market should result in higher returns, in equilibrium. This reasoning generates our second hypothesis:

Hypothesis 2. Firm value will decrease immediately following the announcement and transfer of firms from the main market to the AIM, followed by subsequent higher returns.

\section{Characteristics of the data}

Firm names, announcement dates and implementation dates of listing changes were obtained from the London Stock Exchange "New Issues and IPO Summary" spreadsheet (London Stock Exchange 2011b) and the NexisUK database of aggregated regulatory news from the London Stock Exchange. Close to close trading day periods are used to measure 
total daily shareholder, industry sector, market and risk free returns. Therefore, in all subsequent discussions trading days are referred to simply as days and daily returns are the returns achieved over a close to close period. For all firms, daily excess returns over the contemporaneous risk free rate of interest were calculated by geometric differencing. ${ }^{5}$ Market excess returns are proxied by the capitalization weighted average excess returns of the FTSE AIM All Share Index and the FTSE All Share Index returns. Additional control variables include the small firm premium (SMB) calculated by taking the geometric difference of the FTSE Small Cap Index and the FTSE 100 Index daily total returns; the value premium (VMG) calculated as the geometric difference between the FTSE Value Style Index and the FTSE Growth Style Index; daily trading volume for each firm in the sample; the daily closing bid-ask spread for each firm in the sample; the number of shares outstanding and finally the percentage free float for each firm in the sample from the $19^{\text {th }}$ April 2002 when it first became available on Thomson Reuters DataStream.

Firms were sorted into two groups, those transferring from the AIM to the main market (AIM2MAIN) and those transferring from the main market to the AIM (MAIN2AIM). Our sample period began in January 1996 and ended in December 2010, although there were no switches until 1997.

Figure 1 shows that the number of AIM2MAIN firms peaked in 1998 and subsequently declined to a trough of just 2 firms in 2005 before increasing again in 2007 and 2008. The number of MAIN2AIM firms moving in the opposite direction peaked in 2003 before declining in 2009 to the lowest level since 1996. Between 2000 and 2006 the number of MAIN2AIM migrations exceeded the number of AIM2MAIN migrations, a pattern reversed with the onset of the financial crisis in 2007. The number of firms moving in each direction does not correspond with general fluctuations in the stock market. The peak of MAIN2AIM migrations occurred in 2003 when the market reached a low point, and the number of

\footnotetext{
${ }^{5}$ UK Treasury Bill Tender 3 Month Yield Middle Rate, (DataStream Code UKTBTND).
} 
AIM2MAIN migrations subsequently increased relative to MAIN2AIM during the onset of the financial crisis in 2007 and remained higher through 2010, the final year of the study.

Insert Figure 1 about here

\subsection{AIM2MAIN firms}

After excluding foreign firms, firms with missing data and firms with non UK ISIN numbers, we are left with a sample of 111 firms which migrated from the AIM to main market. The reasons given by firms in their announcements for transferring their listing are summarized in Table 1 . The statements of $42 \%$ of the AIM2MAIN firms do not contain any justification of the re-listing decision. The migrations of 40 of the remaining firms coincides with a positive growth forecast or statement that the main market is now appropriate given the firm's size, 39 believe it will raise their profile, 36 believe a move to the main market will increase their shareholder base, and 30 explicitly state an expected improvement in liquidity among their motivations. Other reasons given include better regulation, easier to enact mergers and acquisitions, better analyst coverage and ability to attract talented personnel.

In Table 2, it is reported that the majority of AIM2MAIN firms are from the DataStream consumer services sector (24) followed closely by financials (31), industrials (18), technology (14) and healthcare (11). The remaining five sectors - oil and gas, telecoms, utilities, basic materials and consumer goods - comprise a total of just 13 firms. Of the 111 firms in the sample, the median number of trading days between the announcement of a listing change and its enactment (implementation lag) is 39, the maximum is 607 and the 
minimum is 0 (one firm only: Staffware. ${ }^{6}$ The median market capitalization on the implementation day is $£ 122.5 \mathrm{~m}$ and the maximum is $£ 1.1 \mathrm{bn}$.

Insert Table 2 about here

\subsection{MAIN2AIM firms}

After excluding foreign firms, firms with missing data and firms with non UK ISIN numbers, we are left with a sample of 262 firms which migrated from the main to the AIM section, including MDY Healthcare which is entered twice because it moved from the main market to the AIM, back to the main market and then back to the AIM a second time. From Table 1 , it is evident that $16 \%$ of MAIN2AIM firms, compared to $42 \%$ of AIM2MAIN firms, do not feel the need to justify their move to shareholders. Half of the firms state that the migration will facilitate the growth of the firm and that the new market is more appropriate for the firm's size. More favourable regulation is also frequently cited as a motivation for the $48 \%$ of the MAIN2AIM group. General flexibility regarding corporate transactions is mentioned in $40 \%$ of the statements justifying migration, while about $11 \%$ mention some form of restructuring process.

Examination of Table 2 reveals that the median implementation lag is 23 days which is quicker than the 39 day median observed in the AIM2MAIN sample. Two firms moved just ten days from the announcement day. ${ }^{7}$ A short implementation lag is potentially damaging

\footnotetext{
${ }^{6}$ Under AIM Rule 41 "An AIM company which wishes the Exchange to cancel admission of its AIM securities must notify the Exchange of its preferred cancellation date at least twenty business days prior to such date and save where the Exchange otherwise agrees, the cancellation shall be conditional upon the consent of not less than $75 \%$ of votes cast by its shareholders given in a general meeting." However, in the case of firms moving from the AIM to the main market, firms can seek a waiver of rule 41 from the AIM regulation team of the London Stock Exchange. Waivers are considered on a case by case basis. This was confirmed by a telephone conversation by the author with a representative of the AIM regulation team on the $21^{\text {st }}$ of August 2008.

${ }^{7}$ As applicable at August 2008, under UKLA rule 5.2.5 par. 2 a firm must obtain prior approval of a resolution for cancellation of not less than $75 \%$ of shareholders at a general meeting. Firms must also inform shareholders that the resolution for cancellation has been passed within 20 days following the date of the resolution and inform them of the intended date of cancellation. However, both UKLA rules 5.2.7 and 5.2.12 outline situations where rule 5.2.5 does not apply and firms are only required to provide advance notice of 20 business days before the intended cancellation of listing. In addition, a conversation between one of the
} 
for private investors who may not be aware of the weaker shareholder protection mechanisms available on the AIM, particularly in situations where the requirements for a consultation period and shareholder approval for a delisting from the main market to the AIM are waived. It is also evident from Table 2 that the distribution of firms between sectors is somewhat different in the MAIN2AIM compared to the AIM2MAIN sample. The sector containing the most firms is industrials (79) followed by consumer services (44), consumer goods (41), technology (41) and financials (32). The remaining five sectors basic materials, utilities, telecoms, oil and gas and healthcare - comprise 24 firms.

At $£ 9 \mathrm{~m}$ the implementation day median market capitalization is much lower for the MAIN2AIM firms than the $£ 123 \mathrm{~m}$ median observed for the AIM2MAIN firms. This is consistent with the findings of Gerakos, Lang and Maffet (2013) to the effect that AIM2MAIN firms are likely to have exhibited recent growth and good performance while MAIN2AIM firms are likely to have exhibited poor performance and retrenchment.

\subsection{Survival record of switching firms}

A substantial proportion of both groups of firms ceased trading after their listing change, as summarized in Table 3.

Insert Table 3 about here

Of the 111 AIM2MAIN firms, a total of $52 \%$ were classified by DataStream as no longer in existence by $4^{\text {th }}$ March 2011. Of all the AIM2MAIN firms, $41 \%$ survived for more than 5 years after migration and a clear majority survived for more than 3 years. The post implementation survival of the MAIN2AIM firms is similar to the AIM2MAIN counterparts as a total $52 \%$ of firms are classified as dead by the end of the study period. The rate at

authors and a member of the technical team at the UKLA on the $22^{\text {nd }}$ August 2008 indicated that in exceptional circumstances, the requirement of a minimum of 20 business days of notice may also be waived. Nonetheless, Jenkinson and Ramadorai (2012) report that the rules were applied more rigorously from 2007 onwards and indeed, we find that from the beginning of 2007 the minimum implementation lag increased to 38 trading days and the median to 39 days. 
which MAIN2AIM firms die over the study period is similar to that of the AIM2MAIN sample and the majority of firms survive for 5 years or more, following migration.

\subsection{Choice of event date}

Standard event studies aim to capture the value of price sensitive information released on the event date which is reflected in the difference between the realized return and the expected return, based upon a return-generating model.

Many of the listing change announcements coincide with the release of other price sensitive information, such as annual results, interim results, fundraisings, trading statements and takeover bids. We hypothesize that promotions to the main market from AIM are likely to be associated with positive news, while transfers from the main market to the AIM are likely to be associated with unfavourable news, reflecting the possibility that a listing change may be a symptom rather than a cause of firm performance. Hence, we are able to make useful inferences about the overall health of firms making the respective announcements, both as reported on the announcement day and in the period leading up to the announcement by studying their price reaction on the announcement date.

We found little evidence of firms releasing additional price sensitive information on the implementation date, making this date 'clean' of confounding events. Implementation conveys the removal of the uncertainty, or execution risk. In the case of AIM2MAIN firms, it is also confirmation of the ability to meet the listing requirements of the main market. An event study based on the implementation date is also able to capture the effects of changes in liquidity arising as different categories of investors move into or out of a firm's stock around the migration date.

\section{Hypothesis testing and results}

\subsection{Returns surrounding listing migrations}

It is evident from Table 1 that a frequently cited motivation for a listing switch is to improve liquidity. Furthermore, switching firms are often small relative to the average size 
of firms listed on the LSE; they may be in high growth sectors; they may have higher or lower sensitivity to market risk than average; or they may have a higher or lower trading volume relative to similar firms. Therefore, in order to control for firm and time specific factors we specify our return generating model I for which independent variables are identified in the left column of Table 4. Least squared coefficients for model I are estimated for each firm, with individual excess returns used as the dependent variable. Time series data from 250 days prior to the announcement through to 250 days after the implementation date, the end of the study period, or the firm death date, whichever is first, are used to estimate the coefficients. Event day abnormal returns are captured using dummy variables for the announcement date and implementation date. The long run pre implementation and post implementation change to the agency risk premium are captured by the model intercept and intercept dummy variable coefficients respectively.

Insert Table 4 about here

Consistent with our two hypotheses, the results in Table 4 show that the announcement day abnormal return dummy variable coefficient is positive and significant at the $p<0.05$ level for the AIM2MAIN group but negative and significant at the $p<0.01$ level for the MAIN2AIM group. The signs of the implementation day abnormal return dummy variable coefficients are also consistent with our hypotheses, although only the MAIN2AIM sample is significant at the $\mathrm{p}<0.05$ level. Likewise, the mean coefficients on the intercept dummy variables are negative for the AIM2MAIN sample and positive for the MAIN2AIM sample in line with our hypotheses, while the test statistics are significant at the $\mathrm{p}<0.01$ and $\mathrm{p}<$ 0.05 levels respectively. Thus on a risk adjusted basis, the value of firms transferring to the main market increases immediately following the announcement and transfer to the main market, but subsequent risk adjusted returns are negative as in hypothesis one. In contrast, the value of firms transferring to the AIM market decreases immediately following the 
announcement and implementation but subsequent returns are positive as predicted by hypothesis two. These findings are consistent with those of Tse and Davos (2004) with respect to AMEX - NASDAQ - AMEX migrations.

Examination of the control variable coefficients reported in Table 4 shows that in the AIM2MAIN sample the interaction dummy variable coefficient testing for changes in firms' sensitivity to the market return post implementation is not significant, while for the MAIN2AIM sample the coefficient is negative and significant, at the $\mathrm{p}<0.05$ level. This indicates that MAIN2AIM firms' sensitivities to market returns, i.e. betas, decline post migration. This finding mirrors that of Bacman et al. (2002) who observe increases in market risk for firms that migrate up to the senior segment of the French stock exchange. We argue that market risk becomes less relevant than agency risk when firms migrate to AIM. This is because AIM firms often have low liquidity and concentrated ownership, so they arguably have more in common with private equity than firms on the main market and as a consequence issues of control rights are of greater importance. Bonding is lower for AIM firms, with the result that agency risk is higher, creating uncertainty - although this uncertainty is not necessarily observable in the form of stock price volatility. Nonetheless, the uncertainty is priced by a return premium that results in higher total shareholder returns following the downward migration.

To summarize, in hypotheses (1) and (2) we argue that the two sections of the LSE constitute different bonding regimes. Firms migrating between the two regimes are subjected to a change in bonding obligations that directly cause a change in the level of agency risk faced by their minority investors. In other words, in the low bonding regime of the AIM, agency risk is high. Conversely agency risk is low in the high bonding regime of the main section of the LSE. We test our hypotheses using the general specification of return generating model I. This controls for the market, firm size and the book to market risk factors of Fama and French (1993); industry risk; the possible influence of changes in 
liquidity during the pre and post event period on the return generating process (Liu 2006) ${ }^{8}$; and the possibility that return generating model parameters such as the intercept and market risk may differ before and after the implementation date (see for example, Baker and Edelman 1992a; Bacmann et al. 2002; Carlson, Fisher and Giammarino 2010). Following Glosten and Milgrom (1985), the bid-ask-spread variable controls for both liquidity and time variation in information asymmetry. Thus, by a process of eliminating other possible causes, we attribute the abnormal returns isolated by our model to changes in the agency risk premium resulting from switches between the two bonding regimes.

In order to mitigate the potential thin-trading biases identified by Dimson (1979) and others, the specification of model I also includes lagged firm returns, lagged market excess returns and lagged size and style factors. Both groups of firms, but especially firms in the MAIN2AIM sample, frequently experience days when no trading occurs. Therefore, we implement an additional mitigation for thin-trading that, to the best of our knowledge, has not been implemented in prior research. Specifically, we substitute market excess returns for firm excess returns on days when both of the following two conditions are met simultaneously: (a) a firm's stock price does not change and (b) its trading volume is zero. These two conditions amount to missing data, because on zero volume days a return of zero does not necessarily reflect the return an investor could have made had they attempted to trade. Hence we refer to such days as 'no-price days' (NPDs). Our substitution is motivated by the principle that the least biased substitute for missing firm level data is likely to be the market excess return. We also encounter missing data related to free float and the bid-ask spread: for free float data we substitute $100 \%$ for the missing value, while for bid-ask spread data we substitute the mean bid-ask spread observed for that firm over the 501 day event period.

\footnotetext{
${ }^{8}$ Our approach differs from that of Liu (2006) in that our model I includes contemporaneous and lagged changes in bid ask spread and scaled trading volume, whereas Liu constructs a liquidity risk factor from the return differential between portfolios of low and high liquidity stocks defined according to a liquidity metric. Thus, our method allows for greater time series variation in liquidity within firms.
} 


\subsection{Robustness tests}

We carried out a number of robustness checks of the results reported in Table 4, including: (1) not substituting market returns for firm returns on days when no trading or price change occurred; (2) excluding firms in which the total trading volume in the year prior to implementation was less than $3 \%$ of shares outstanding; (3) varying the specification of model I to include additional lags on the control variables; (4) omitting nonsignificant control variables such as the free float; (5) imposing winsorizations of $2.5 \%$ on each tail; (6) partitioning the data into quartiles of calendar time for implementation dates, quartiles of market capitalization and quartiles of average bid-ask spread one year prior to implementation. In all of our robustness checks we obtained qualitatively similar results with consistent coefficient signs on the key variables of interest, although significance levels naturally vary.

Of course notwithstanding these robustness tests, it is possible that other factors might explain the returns which we attribute to changes in agency risk. In a further effort to investigate competing explanations for our results we undertake a cross sectional analysis using a second model. Dependent variables for model II are chosen on the premise that the key relationships of interest in model I are represented by the coefficients on the following variables: (a) the intercept, showing the model-adjusted daily average returns; (b) the intercept dummy variable showing incremental average daily returns observed post implementation (i.e. the change in the agency risk premium); and (c) a separate dummy variable recording the announcement day and implementation day abnormal returns respectively. As systematic variations between firms may not be captured by the averaging of model I coefficients reported in Table 4, we undertake a cross sectional analysis of the above four key coefficients from model I. This is achieved by setting each coefficient as the dependent variable in four variations of a cross sectional regression of model II.

The independent variables in model II are listed in Tables 5 and 6 for the two groups of firms respectively. For each firm they include: the model I coefficients other than the 
respective dependent variable in model II; the market value percentile rank on the implementation day relative to the whole sample migration category; the average bid-ask spread percentage over the period $\mathrm{t}_{-255}$ through $\mathrm{t}_{-6}$; the standardized daily trading volume; the average free float percentage over the period $t_{-255}$ through $t_{-6}$ and the implementation lag in trading days. In addition, we include dummy variables identifying whether or not other information such as financial results were disclosed on the announcement date; whether additional capital was raised at the time of the migration and whether shareholders were given a vote on the proposed migration; and dummy variables identifying the stated motivation for the migration, as described in Table 1.

The basic premise of model II is that there may be associations between firm characteristics and the abnormal returns identified using model I. Investigation of betweenfirm variation in model I coefficients with the aid of a cross sectional regression allows a richer exploration of the data than a panel estimation using either fixed or random effects. This is because the cross sectional regression takes into account between firm variations in both slope and intercept coefficients in model I.

Insert Table 5 about here

Examination of Tables 5 and 6 confirm that for both groups of firms, relatively few of the coefficients in model II are significant at the $\mathrm{p}<0.10$ level or less and the low adjusted $\mathrm{R}^{2}$ values indicate that overall, the variables in model II explain little of the abnormal returns identified in model I. In other words, the results of model II do not support competing explanations to our bonding and agency risk theories underpinning hypotheses (1) and (2). Nonetheless, the model II coefficients that are significant at the $<0.10$ level or less indicate that for the AIM2MAIN sample, firms which exhibit the greatest pre-implementation abnormal returns undergo the greatest reversal in fortunes following implementation, as evidenced by the negative relationship between the model I intercept dummy and model I 
intercept coefficients, significant at $\mathrm{p}<0.05$. In a study of firms seeking promotion from the American Stock Exchange (AMEX) to the New York Stock Exchange (NYSE), Baker and Edelman (1992a) observe a similar pre migration rise in firm values and a post migration fall. Comparable results with respect to upward migrations on the Tokyo Stock Exchange (TSE) are found by Lamba and Arif (1997).

Insert Table 6 about here

Corresponding model II coefficients for the MAIN2AIM sample are reported in Table 6. Even fewer of the model II coefficients are significant and the adjusted $\mathrm{R}^{2}$ values are lower still, further reducing the potential for competing explanations for the abnormal returns observed in model I. Overall, the weak significance of the model II coefficients with respect to MAIN2AIM is reassuring as it implies that most of the relevant information is captured by model I, with little new information added by model II.

In sections 2 and 4 we also mention that tax differences between the two segments might result in trading around listing migrations as different tax clienteles of investors move into or out of the migrating firm in order to benefit from or avoid losing tax reliefs as a result of the migration. Of course it is possible that tax, or similar clientele related changes in the investor base of firms, may result in the abnormal returns observed. However, if this is the case, the results appear somewhat counter intuitive given that loss of the reliefs available to firms migrating from the AIM to the main section might be expected to result in shareholders exiting the firm and prices being depressed prior to the migration. In fact, our results appear to be the opposite, leading us to suggest that changes in agency risk outweigh any tax clientele effects that may result from the switch. Arguably, our results are strengthened by the fact that the tax benefits of a migration to AIM do not counterbalance the negative influence of increased agency risk. It is also worth noting that the stated 
motivation of achieving 'tax benefits to investors' for firms migrating down to the AIM is not significant in the results reported in Table 6. Furthermore, our model I specification indirectly controls for transitory changes in liquidity around the listing migrations by including variables that capture time series changes in three liquidity proxies. Therefore, we are confident that the returns that we attribute to differences in bonding and agency risk exist after controlling for trading activity resulting from clientele changes in the investor base.

\section{Summary and conclusions}

After controlling for firm size, market, style, industry and liquidity, we find that firms graduating from the AIM to the main section of the LSE generate positive returns on the day the decision is announced. For firms moving in the opposite direction, corresponding returns are negative. It thus appears that announcements of the intention to move up and down are associated with good and bad news, respectively. After the listing change is implemented, the pattern is reversed for both categories of firm so that firms moving up earn lower returns while firms moving down earn higher returns. For firms transferring down from the main market to the AIM, we argue that the improved performance post implementation is a reward to shareholders for bearing increased levels of agency risk. In contrast, because investors value the higher bonding requirements of the main market, firms transferring up to the main market experience positive returns on the announcement days but subsequently have lower returns that reflect the lower cost of equity capital as a result of reduced agency risk. The fact that post migration returns are abnormal, i.e. persisting after comprehensively controlling for other risk factors, implies that the remaining agency risk earns a return premium additional to that attributable to these other factors.

Our conclusions are subject to the caveat that we have not measured the relationship between bonding cost and firm performance directly. However, we mitigate this concern by including a wide variety of control variables to eliminate competing explanations for our 
results. Our controls demonstrate that liquidity changes do not account for the changes in firm valuation and returns surrounding migrations. Likewise, examination of the survival rates of switching firms provides little evidence that differences in bankruptcy rates, pre and post migration, are a competing explanation for our results.

Our results have important economic implications. The tradeoff between agency risk and bonding costs is relevant to firm managers when determining an appropriate listing venue; investors weighing up the implications of an investee firm's listing choice; and regulators determining appropriate mechanisms of regulatory oversight. Our results indicate that this trade-off determines the switching decision. They also demonstrate the importance of controlling for time series variations in liquidity in return generating models to remove potential omitted variable bias. Bearing in mind both the changes in firm valuation and cost of capital arising as a result of listing changes, these findings are relevant to both AIM and main market investors. More than double the number of firms moved down to the AIM from the main market as moved in the opposite direction. The median size of firms transferring to the main market is thirteen and a half times larger than firms moving down to the AIM. Hence it seems plausible that firms moving down have reached a size at which the additional bonding costs of maintaining a main market listing are no longer outweighed by the reduced cost of capital arising from the lower agency risks of a main market listing. 


\section{References}

Amihud, Y., Mendelson, H., 1986. Asset pricing and bid-ask spread. Journal of Financial Economics 17, $223-249$.

Amira, K., Muzere, M. L., 2011. Competition among stock exchanges for equity. Journal of Banking and Finance 35, 2355-2373.

Arcot, S., Black, J., Owen, G., 2007. From local to global: the rise of AIM as a stock market for growing firms. Report commissioned by London Stock Exchange from The London School of Economics and Political Science.

Bacmann, J.F., Dubois, M., Ertur, C., 2002. Valuation effects of listing on a more prominent segment of the stock market: evidence from France. European Financial Management 8, 479 $-493$.

Baker, H. K., Edelman, R. B., 1992a. AMEX-to-NYSE transfers, market microstructure, and shareholder wealth. Financial Management 21, 60 - 72.

Baker, H. K., Edelman, R. B., 1992b. The effects on spread and volume of switching to the NASDAQ national market system. Financial Analysts Journal 48, $83-88$.

Baker Tilly, 2011.Taking AIM: Annual Survey 2011. June.

Bebchuk, L.A., 2005. The case for increasing shareholder power. Harvard Law Review 118, $833-914$.

Bebchuk, L.A., 2007. The myth of the shareholder franchise. Virginia Law Review 93, 675 $-732$.

Becht, M., Franks, J., Rossi, S., 2009. Returns to shareholder activism: evidence from a clinical study of the Hermes UK Focus Fund. Review of Financial Studies 22, 3093 - 3129. Blackwell, D. 2009. Regal's fine puts focus on AIM regulation. Financial Times, November 19. 
Brau, J.C., Fawcett, S.E., 2006. Initial public offerings: an analysis of theory and practice. The Journal of Finance 61, 399 - 436.

Carpentier, C., Cumming, D., Suret, J. M., 2011. The Valuation Effect of Listing Standards: An Analysis of Canadian and US IPOs. Working Paper, February.

Carlson, M., Fisher, A., Giammarino, R., 2010. SEO risk dynamics. Review of Financial Studies 23, $4026-4077$.

Carvalho, A.G., Pennacchi, G.G., 2012. Can a stock exchange improve corporate behavior? Evidence from firms' migration to premium listings in Brazil. Journal of Corporate Finance $18,883-903$

Chemmanur, T.J., Fulghieri, P., 2006. Competition and co-operation among exchanges: A theory of cross-listing and endogenous listing standards. Journal of Financial Economics 82, $455-489$.

Clyde, P., Schultz, P., Zaman, M., 1997. Trading costs and exchange delisting: the case of firms that voluntarily move from the American stock exchange to the NASDAQ. The Journal of Finance 52, 2103 - 2112.

Coffee, J.C., 1999. The future as history: the prospects for global convergence in corporate governance and its implications. Northwestern University Law Review 93, 641 - 708.

Core, J., Holthausen, R., Larcker, D. 1999. Corporate Governance, Chief Executive Officer Compensation, and Firm Performance. Journal of Financial Economics 51, 371-406.

Dimson, E., 1979. Risk measurement when shares are subject to infrequent trading, Journal of Financial Economics 7, $197-226$.

Doidge, C., Karolyi, G.A., Stulz, R.M., 2007. Why do countries matter so much for corporate governance? Journal of Financial Economics 86, 1 - 39 .

Espenlaub, S., Khurshed, A. Mohamed, A., 2012. IPO survival in a reputational market. Journal of Business Finance and Accounting 33, 427 - 463. 
Fama, E.F., French, K.R., 1993. Common risk factors in the returns on stocks and bonds. Journal of Financial Economics 33, 3 - 56.

Financial Reporting Council. 2010. The UK Corporate Governance Code. Available at: http://www.frc.org.uk/documents/pagemanager/Corporate_Governance/UK Corp Gov Code June 2010.pdf

Foerster, R., Karolyi, A., 1999. The effects of market segmentation and investor recognition on asset prices: evidence from foreign stocks listing in the United States. Journal of Finance $54,981-1013$.

Gerakos, J. J., Lang, M. H., Maffett, M. G., 2013. Post-listing performance and private sector regulation: The experience of London's Alternative Investment Market. Journal of Accounting and Economics 56, Supplement 1, 189 - 215.

Glosten, L.R., Milgrom, P.R., 1985. Bid, ask, and transaction prices in a specialist market with heterogeneously informed traders. Journal of Financial Economics 14, 71-100.

Goyal, V., Park, C. 2002. Board leadership structure and CEO turnover. Journal of Corporate Finance 8, 49-66.

Hail, L., Leuz, C., 2009. Cost of capital effects and changes in growth expectations around U.S. cross-listings. Journal of Financial Economics 93, 428 - 454.

Jenkinson, T., Ramadorai, T., 2013. Does one size fit all? The consequences of switching markets with different regulatory standards. European Financial Management 19, 852 - 886. Kadlec, G., McConnell, J., 1994. The effect of market segmentation and illiquidity on asset prices: Evidence from exchange listings. Journal of Finance 49, 611 - 636.

Knight, F. H., 1985. Risk, Uncertainty and Profit, University of Chicago Press, Chicago. (First published by Houghton Mifflin, Boston in 1921).

Lamba, A. S., Ariff, M., 1997. The information content of firms switching from section 2 to section 1 of the Tokyo stock exchange. Pacific-Basin Finance Journal 5, $441-463$. 
Lamba, A. S., Khan, W.A., 1999. Exchange listings and delistings: the role of insider information and insider trading. The Journal of Financial Research 22, $131-146$.

La Porta, R., Lopez-De-Silanes, F., Shleifer, A., Vishny, R.W., 1997. Legal determinants of external finance. Journal of Finance 52, $1131-1150$.

La Porta, R., Lopez-De-Silanes, F., Shleifer, A., Vishny, R.W., 1998. Law and finance. The Journal of Political Economy 106, 1113 - 1155.

La Porta, R., Lopez-De-Silanes, F., Shleifer, A., 1999. Corporate ownership around the world. Journal of Finance 54, 471 - 517.

Leitterstorf, S. Nicoletti, P., Winkler, C., 2008. The UK Listing Rules and Firm Valuation. Financial Services Authority Occasional Paper Series 28, available at: http://www.fsa.gov.uk/pubs/occpapers/op28.pdf

Lel, U., Miller, D., 2008. International crosslisting, firm performance and top management turnover: A test of the bonding hypothesis. Journal of Finance 63, 1897-937.

Leuz, C., Triantis, A., Wang, T.Y., 2008. Why do firms go dark? Causes and economic consequences of voluntary SEC deregistrations. Journal of Accounting Economics 45, 181 208.

Liu, W., 2006. A liquidity-augmented Capital Asset Pricing Model. Journal of Financial Economics 82, $631-671$.

London Stock Exchange, 2007a. AIM Rules for Nominated Advisers. February. Accessed in April 2013 at:

http://www.londonstockexchange.com/companies-and-advisors/aim/publications/aim-rulesfor-nominated-advisers.pdf

London Stock Exchange, 2007b. Stock Exchange AIM Disciplinary Notice: Public censure and fine - Nabarro Wells \& Co Limited. Accessed in April 2013 at: 
http://www.londonstockexchange.com/companies-and-advisors/aim/advisers/aim$\underline{\text { notices/ad1v4-clean.pdf }}$

London Stock Exchange, 2009. Stock Exchange AIM Disciplinary Notice: Public censure and fine - Astaire Securities plc (formerly Blue Oar Securities plc). Accessed in April 2013 at:

http://www.londonstockexchange.com/companies-and-advisors/aim/advisers/aimnotices/ad8-disciplinary-notice.pdf London Stock Exchange, 2010. AIM Rules for Companies. February. Accessed in April 2013 at:

http://www.londonstockexchange.com/companies-and-advisors/aim/advisers/rules/aimrules-for-companies.pdf London Stock Exchange, 2011a. List of all companies. Accessed in April 2011 at: http://www.londonstockexchange.com/statistics/companies-and-issuers/companies-and$\underline{\text { issuers.htm }}$

London Stock Exchange, 2011b. New Issues and IPO Summary. Accessed in March 2011 at: http://www.londonstockexchange.com/statistics/new-issues...issues/new-issues.xls London Stock Exchange, 2011c. Stock Exchange AIM Disciplinary Notice: Public censure and fine - Seymour Pierce limited. Accessed in April 2013 at:

http://www.londonstockexchange.com/companies-and-advisors/aim/advisers/aimnotices/aim-notice-ad11.pdf MacNeil, I., Li, X., 2006. "Comply or explain": market discipline and non-compliance with the Combined Code. Corporate Governance: An International Review 14, 486 - 496.

Mallin, C., Ow-Yong, K., 1998. Corporate governance in small firms - the Alternative Investment Market. Corporate Governance: An International Review 6, 224 - 232. 
Mallin, C.,Ow-Yong, K., 2008. Corporate Governance in the Alternative Investment Market (AIM) Firms. Institute of Chartered Accountants of Scotland, Research Report.

Mallin, C., Ow-Yong, K., 2010. The Alternative Investment Market - ethical dimensions. Journal of Business Ethics 95, 223 - 239.

Mendoza, J.M., 2008, Securities regulation in low-tier listing venues: the rise of the Alternative Investment Market. Fordham Journal of Corporate \& Financial Law 3, 257-328. Available at SSRN: http://ssrn.com/abstract $=1004548$

Merton, R., 1987. Presidential address: a simple model of capital market equilibrium with incomplete information. Journal of Finance 42, 483 - 510.

Nielsson, U., 2013. Do less regulated markets attract lower quality firms? Evidence from the London AIM Market. Journal of Financial Intermediation, doi: http://dx.doi.org/10.1016/j.jfi.2012.11.005

Pagano, M., Roell, A., Zechner, J., 2002. The geography of equity listing: why do firms list abroad? Journal of Finance 57, $2651-2694$.

Piotroski, J.D., Srinivasan, S., 2008. Regulation and bonding: the Sarbanes-Oxley Act and the flow of international listings, Journal of Accounting Research 46, $383-425$.

Quoted Companies Alliance, 2010. Corporate Governance Guidelines for Smaller Quoted Companies, September.

Rosenstein, S., Wyatt, J., 1990. Outside directors, board independence and shareholder wealth. Journal of Financial Economics 26, 175 - 191.

Skaife, H.A., Collins, D.W., LaFond, R., 2004. Corporate Governance and the Cost of Capital, Working paper available at: http://ssrn.com/abstract=639681.

Snell, D., O'Brien, S., 2008. Corporate governance and AIM: An assessment of the governance procedures adopted by AIM firms. London: PricewaterhouseCoopers, available at: http://www.pwc.co.uk/pdf/corporate_governance_aim.pdf 
Stulz, R., 1999. Globalization, corporate finance, and the cost of capital. Journal of Applied Corporate Finance 26, 3-28.

Tse, Y., Devos, E., 2004. Trading costs, investor recognition and market response: An analysis of firms that move from the Amex (Nasdaq) to Nasdaq (Amex). Journal of Banking and Finance 28, $63-83$.

Taylor, P., 2009. Astaire's Public Punishment is a Warning to Others. The Telegraph, June 28.

Vismara, S., Paleari, S., Ritter, J.R., 2012. Europe's second market for small firms. European Financial Management 18, 352 - 388. 
Table 1

$\underline{\text { Justifications for a Change of Listing }}$

\begin{tabular}{lcccc}
\hline Justification Category & \multicolumn{2}{c}{$\begin{array}{c}\text { AIM2MAIN } \\
\text { No. \& \% }\end{array}$} & $\begin{array}{c}\text { MAIN2AIM } \\
\text { No. \& \% }\end{array}$ \\
\hline No justification & 47 & $42.3 \%$ & 41 & $15.6 \%$ \\
Growth and/or appropriate for firm's size & 40 & $36.0 \%$ & 131 & $49.8 \%$ \\
Raised profile of company or market & 39 & $35.1 \%$ & 6 & $2.3 \%$ \\
Increase investor base & 36 & $32.4 \%$ & 20 & $7.6 \%$ \\
Improve liquidity/appropriate for current liquidity & 30 & $27.0 \%$ & 12 & $4.6 \%$ \\
Placing/capital raising concurrent with switch & 11 & $9.9 \%$ & 38 & $14.4 \%$ \\
Ease of future capital raising & 4 & $3.6 \%$ & 14 & $5.3 \%$ \\
Ease of future acquisitions & 2 & $1.8 \%$ & 38 & $14.4 \%$ \\
Attract staff & 2 & $1.8 \%$ & 1 & $0.4 \%$ \\
Cost savings, simplification of reporting/regulation & 0 & 0 & 127 & $48.3 \%$ \\
General flexibility regarding corporate transactions & 0 & 0 & 105 & $39.9 \%$ \\
Tax benefits for investors & 0 & 0 & 34 & $12.9 \%$ \\
Restructuring/refocusing/refinancing/write down & 0 & 0 & 28 & $10.6 \%$ \\
Violates minimum 25\% free-float rule, or similar & 0 & 0 & 17 & $6.5 \%$ \\
SuiTable for existing investor base & 0 & 0 & 15 & $5.7 \%$ \\
High proportion of private investors & 0 & 0 & 4 & $1.5 \%$ \\
Shareholder protection statement & 0 & 0 & 37 & $14.1 \%$ \\
\hline Total number of justifications in each sample & 164 & & 616 & \\
Total number of firms in each sample & 111 & & 262 & \\
Average proportion of total justification categories & NA & $18.5 \%$ & NA & $15.0 \%$ \\
Maximum proportion of total justification categories & NA & $87.5 \%$ & NA & $53.3 \%$ \\
\hline
\end{tabular}

AIM2MAIN firms are those that transfer from the AIM to the main market. MAIN2AIM firms are those transferring in the opposite direction. The first announcement of the intended change of listing was searched for a statement justifying the change. Statements were then grouped into the categories identified below, the titles of which record the meaning of, or paraphrase, the justifications provided by the individual firms. Some firms gave multiple justifications; hence, the total number of justifications in each sample is greater than the total number of firms despite the fact that $42.3 \%$ of AIM2MAIN and $15.6 \%$ of MAIN2AIM firms do not give any justification. The average disclosure proportion reflects the average of the number of justifications given by each firm divided by the total number of justification categories identified below. The category "shareholder protection statement" records firms in the MAIN2AIM sample that found it necessary to reassure investors that their interests would not be adversely affected by the switch. 
Table 2

Characteristics of Transferring Firms

\begin{tabular}{|c|c|c|c|c|}
\hline \multirow{2}{*}{$\begin{array}{l}\text { Firm Characteristics } \\
\text { Total }\end{array}$} & \multicolumn{2}{|c|}{ AIM2MAIN No. \& \% } & \multicolumn{2}{|c|}{ MAIN2AIM No. \& \% } \\
\hline & 111 & $(100 \%)$ & 262 & $(100 \%)$ \\
\hline Consumer Services & 24 & $(22 \%)$ & 44 & $(17 \%)$ \\
\hline Financials & 31 & $(28 \%)$ & 32 & $(12 \%)$ \\
\hline Industrials & 18 & $(16 \%)$ & 79 & $(30 \%)$ \\
\hline Technology & 14 & $(13 \%)$ & 41 & $(16 \%)$ \\
\hline Healthcare & 11 & $(10 \%)$ & 11 & $(4 \%)$ \\
\hline Oil \& Gas & 5 & $(5 \%)$ & 4 & $(2 \%)$ \\
\hline Telecom & 3 & $(3 \%)$ & 3 & $(1 \%)$ \\
\hline Utilities & 3 & $(3 \%)$ & 0 & $(0 \%)$ \\
\hline Basic Materials & 1 & $(1 \%)$ & 6 & $(2 \%)$ \\
\hline Consumer Goods & 1 & $(1 \%)$ & 41 & $(16 \%)$ \\
\hline Min. Imp. lag & & 0 & & 10 \\
\hline $25^{\text {th }}$ percentile of the Imp. lag & & 20 & & 21 \\
\hline $50^{\text {th }}$ percentile of the Imp. lag & & 39 & & 23 \\
\hline $75^{\text {th }}$ percentile of the Imp. lag & & 115 & & 40 \\
\hline Max. Imp. Lag & & 607 & & 201 \\
\hline Min. Mkt. Cap. Imp. Day & & $£ 1.6 \mathrm{~m}$ & & $£ 0.3 \mathrm{~m}$ \\
\hline $25^{\text {th }}$ percentile of the Mkt. Cap. Imp. Day & & $£ 49.6 \mathrm{~m}$ & & $£ 4.7 \mathrm{~m}$ \\
\hline $50^{\text {th }}$ percentile of the Mkt. Cap. Imp. Day & & $£ 122.5$ & & $£ 9.1 \mathrm{~m}$ \\
\hline $75^{\text {th }}$ percentile of the Mkt. Cap. Imp. Day & & $£ 255.3$ & & $£ 19.7 \mathrm{~m}$ \\
\hline Max. Mkt. Cap. Imp. Day & & $£ 1,098 \mathrm{~m}$ & & $£ 338 \mathrm{~m}$ \\
\hline Min. Av. BAS $t-255$ through $t-6$ & & $0.4 \%$ & & $1.5 \%$ \\
\hline $25^{\text {th }}$ percentile of Av. BAS $t-255$ through $t-6$ & & $2.1 \%$ & & $6.0 \%$ \\
\hline $50^{\text {th }}$ percentile of Av. BAS $t-255$ through $t-6$ & & $3.2 \%$ & & $8.7 \%$ \\
\hline $75^{\text {th }}$ percentile of Av. BAS $t-255$ through $t-6$ & & $4.5 \%$ & & $12.1 \%$ \\
\hline Max. Av. BAS $\mathrm{t}-255$ through $\mathrm{t}-6$ & & $22.6 \%$ & & $37.1 \%$ \\
\hline Min. NPD Proportion, $\mathrm{t}-255$ through $\mathrm{t}-6$ & & 0 & & 0 \\
\hline $25^{\text {th }}$ percentile NPD Proportion, $t-255$ through $t-6$ & & 0 & & $6.8 \%$ \\
\hline $50^{\text {th }}$ percentile NPD Proportion, $\mathrm{t}-255$ through $\mathrm{t}-6$ & & $6.0 \%$ & & $26.6 \%$ \\
\hline $75^{\text {th }}$ percentile NPD Proportion, $\mathrm{t}-255$ through $\mathrm{t}-6$ & & $27.2 \%$ & & $58.4 \%$ \\
\hline Max. NPD Proportion, $\mathrm{t}-255$ through $\mathrm{t}-6$ & & $85.8 \%$ & & $100 \%$ \\
\hline
\end{tabular}

AIM2MAIN firms are those that migrate from the AIM to the main market. MAIN2AIM firms are those migrating in the opposite direction. Other abbreviations are as follows: number of observations (No.), largest observation (Max.), smallest observation (Min.), average (Av.), market capitalization (Mkt. Cap.), implementation (Imp.), bid-ask spread (BAS), no price days in which both trading volume and price changes are zero (NPD). 
Table 3

Firms Dying Between the Implementation Date and the $4^{\text {th }}$ March 2011

\begin{tabular}{|c|c|c|c|c|}
\hline \multirow{2}{*}{$\begin{array}{l}\text { Death period from implementation date } \\
\text { Within } 1 \text { year ( } 250 \text { trading days })\end{array}$} & \multicolumn{2}{|c|}{ AIM2MAIN } & \multicolumn{2}{|c|}{ MAIN2AIM } \\
\hline & 2 & $(2 \%)$ & 23 & $(9 \%)$ \\
\hline Between 1 and 2 years & 15 & $(15 \%)$ & 24 & $(9 \%)$ \\
\hline Between 2 and 3 years & 5 & $(5 \%)$ & 18 & $(7 \%)$ \\
\hline Between 3 and 5 years & 14 & $(13 \%)$ & 33 & $(13 \%)$ \\
\hline More than 5 years & 46 & $(41 \%)$ & 132 & $(50 \%)$ \\
\hline $\begin{array}{l}\text { Moved }<5 \text { years before } 4^{\text {th }} \text { March } 2011 \text { and } \\
\text { alive at } 4^{\text {th }} \text { March } 2011\end{array}$ & 30 & $(27 \%)$ & 33 & $(13 \%)$ \\
\hline Total deaths up to $4^{\text {th }}$ March 2011 & 58 & $(52 \%)$ & 136 & $(52 \%)$ \\
\hline Total number of switching firms & 111 & $(100 \%)$ & 262 & $(100 \%)$ \\
\hline \multicolumn{5}{|l|}{ DataStream Death Category } \\
\hline Delisted & 4 & $(5 \%)$ & 20 & $(8 \%)$ \\
\hline Suspended & 3 & $(2 \%)$ & 4 & $(2 \%)$ \\
\hline Taken Over & 7 & $(6 \%)$ & 11 & $(4 \%)$ \\
\hline Dead - dead (unclassified) & 44 & $(40 \%)$ & 101 & $(39 \%)$ \\
\hline Total (percentages rounded) & 58 & $(52 \%)$ & 136 & $(52 \%)$ \\
\hline
\end{tabular}

AIM2MAIN firms are those that transfer from the AIM to the main market. MAIN2AIM firms are those transferring in the opposite direction. Death lag refers to the number of trading days between the implementation date and firm death. The final check for dead firms was made at the end of the study period on the $4^{\text {th }}$ March 2011. DataStream classifies firms which are inactive, but have not been taken over, suspended, or delisted, as 'dead - dead'. 


\section{Table 4}

Return generating model I variables, coefficients and $\mathrm{t}$ - statistics

\begin{tabular}{|c|c|c|}
\hline \multicolumn{3}{|l|}{ Panel A: AIM2MAIN sample } \\
\hline Independent variables & $\begin{array}{l}\text { Mean } \\
\text { coefficient }\end{array}$ & $t$ - statistics \\
\hline Intercept (average model adjusted abnormal return) & -0.001 & -1.03 \\
\hline Intercept dummy (change in abnormal return following implementation) & -0.001 & $-2.63 * * *$ \\
\hline Announcement day average abnormal return (dummy variable) & 0.022 & $2.53 * *$ \\
\hline Implementation day average abnormal return (dummy variable) & 0.002 & 0.55 \\
\hline Market interaction dummy variable & 0.064 & 1.56 \\
\hline Market excess return & 0.991 & $16.59 * * *$ \\
\hline Market return lagged one period & -0.051 & $-1.807 *$ \\
\hline Small firm return minus large firm return (SMB) & 0.541 & $10.88 * * *$ \\
\hline SMB lagged one period & -0.011 & -0.40 \\
\hline Value firm return minus growth firm return (VMG) & -0.114 & $-3.31 * * *$ \\
\hline VMG lagged one period & -0.062 & $-1.87 *$ \\
\hline Industry residual return & 0.034 & 1.44 \\
\hline Industry residual return lagged one period & 0.014 & 0.87 \\
\hline Change in $\%$ bid-ask spread & -0.004 & $-4.70 * * *$ \\
\hline Volume of shares traded as a $\%$ shares outstanding & 1.847 & $2.31 * *$ \\
\hline Free float percentage & -0.000 & -0.13 \\
\hline Firm excess return lagged one period & 0.075 & $7.57 * * *$ \\
\hline \multicolumn{3}{|l|}{ Panel B: MAIN2AIM sample } \\
\hline Independent variables & $\begin{array}{c}\text { Mean } \\
\text { coefficient }\end{array}$ & $t$ - statistic \\
\hline Intercept (average model adjusted abnormal return) & -0.002 & -1.03 \\
\hline Intercept dummy (change in abnormal return following implementation) & 0.001 & $2.10 * *$ \\
\hline Announcement day average abnormal return (dummy variable) & -0.028 & $-2.98 * * *$ \\
\hline Implementation day average abnormal return (dummy variable) & -0.018 & $-2.27 * *$ \\
\hline Market interaction dummy variable & -0.067 & $-2.29 * *$ \\
\hline Market excess return & 0.830 & $25.67 * * *$ \\
\hline Market return lagged one period & 0.005 & 0.21 \\
\hline Small firm return minus large firm return (SMB) & 0.411 & $13.52 * * *$ \\
\hline SMB lagged one period & 0.040 & 1.88 \\
\hline Value firm return minus growth firm return (VMG) & -0.009 & -0.30 \\
\hline VMG lagged one period & -0.031 & -1.13 \\
\hline Industry residual return & -0.024 & -1.12 \\
\hline Industry residual return lagged one period & 0.026 & 1.44 \\
\hline Change in \% bid-ask spread & -0.012 & $-7.93 * * *$ \\
\hline Volume of shares traded as a $\%$ shares outstanding & 2.751 & $3.14 * * *$ \\
\hline Free float percentage & -0.001 & -0.82 \\
\hline Firm excess return lagged one period & 0.043 & $6.35 * * *$ \\
\hline
\end{tabular}

AIM2MAIN firms are those that transfer from the AIM to the main market. MAIN2AIM firms are those transferring in the opposite direction. The dependent variable is the firm daily excess return. Least squares coefficient estimates are averaged across the respective samples.

$* * *, * *, *$ indicate significance at the $0.01,0.05$ and 0.10 level respectively. 
Table 5

Cross sectional Model II coefficients: firms migrating to the main market, AIM2MAIN

\begin{tabular}{|c|c|c|c|c|}
\hline \multirow[b]{2}{*}{ Independent variables of model II } & \multicolumn{4}{|c|}{$\begin{array}{l}\text { M. II coefficients \& } \\
\text { Dependent Variables }\end{array}$} \\
\hline & M. I Int. & $\begin{array}{l}\text { M. I. Int. } \\
\text { dummy. }\end{array}$ & $\begin{array}{c}\text { M. I } \\
\text { Ann. Ab. }\end{array}$ & $\begin{array}{l}\text { M. I Imp. } \\
\text { Ab. }\end{array}$ \\
\hline Intercept & 0.004 & 0.002 & -0.046 & -0.034 \\
\hline M. I intercept coefficient & & $-0.059 * *$ & -0.974 & -0.490 \\
\hline M. I intercept dummy & $-1.223 * *$ & & -3.931 & 0.046 \\
\hline M. I Announcement day Ab. return & -0.020 & -0.004 & & 0.015 \\
\hline M. I implementation day Ab. return & -0.057 & 0.000 & 0.083 & \\
\hline M. I Market coefficient & $-0.010^{*}$ & -0.001 & $0.083 * *$ & -0.008 \\
\hline M. I Market interaction coefficient & -0.004 & $-0.002 *$ & 0.017 & 0.012 \\
\hline M. I SMB coefficient & 0.005 & 0.002 & $-0.074 *$ & -0.005 \\
\hline M. I VMG coefficient & 0.000 & $0.002 * *$ & -0.025 & -0.000 \\
\hline Market value percentile rank on implementation day & 0.003 & $-0.003 *$ & -0.007 & 0.030 \\
\hline Bid ask spread average percentage $\mathrm{t}-255$ through $\mathrm{t}-6$ & -0.036 & -0.020 & $-0.970 * *$ & $0.407 * *$ \\
\hline Standardised volume, $\mathrm{t}-255$ through $\mathrm{t}-6$ & -0.004 & -0.001 & 0.040 & -0.006 \\
\hline Average free float, $\mathrm{t}-255$ through $\mathrm{t}-6$ & 0.006 & 0.002 & -0.021 & 0.008 \\
\hline Imp. lag in trading days & -0.000 & -0.000 & -0.000 & 0.000 \\
\hline Other information disclosed at time of announcement & 0.006 & 0.000 & 0.016 & 0.014 \\
\hline Placing / capital raising concurrent with migration & -0.008 & -0.001 & -0.042 & -0.018 \\
\hline Shareholders allowed to vote on proposed migration & -0.007 & 0.000 & -0.003 & 0.010 \\
\hline Stated Motivation for migration, defined in Table 1 & & & & \\
\hline No motivation/justification given & -0.004 & -0.000 & 0.040 & 0.000 \\
\hline Increase investor base & -0.007 & -0.000 & 0.031 & 0.001 \\
\hline Improve liquidity / appropriate for current liquidity & -0.002 & 0.000 & -0.025 & 0.012 \\
\hline Raised profile of company or product market & 0.003 & -0.001 & 0.028 & -0.001 \\
\hline Attract staff & 0.003 & -0.001 & -0.059 & 0.019 \\
\hline Growth and/or appropriate for firm's size & -0.002 & 0.000 & 0.031 & -0.009 \\
\hline Adjusted R squared & $6.7 \%$ & $8.6 \%$ & $9.3 \%$ & $0.5 \%$ \\
\hline
\end{tabular}

Coefficients for the cross sectional Model II in which dependent variables are the model I coefficients that identify abnormal returns, namely: intercept (Int.); intercept dummy variable representing the post implementation abnormal (agency risk premium) return; the announcement day abnormal return; and the implementation day abnormal return t. Abbreviations are: model I (M. I), model II (M.II), intercept (Int.) announcement day (Ann.), implementation day (Imp.), abnormal return (Ab.). Dummy variables include: other information disclosed at time of announcement; placing / capital raised at the time of migration; shareholders allowed to vote on proposed migration and; stated motivations for migration as defined in Table 1 . The following symbols: ***, **, * indicate significance at: $0.01,0.05$ and 0.10 levels respectively. 
Table 6

Cross sectional Model II coefficients: firms migrating to the AIM section, MAIN2AIM

\begin{tabular}{|c|c|c|c|c|}
\hline \multirow[b]{2}{*}{ Independent variables of model II } & \multicolumn{4}{|c|}{$\begin{array}{c}\text { M. II coefficients } \\
\text { \& Dependent Variables }\end{array}$} \\
\hline & M. I Int. & $\begin{array}{l}\text { M. I. Int. } \\
\text { dummy. }\end{array}$ & $\begin{array}{l}\text { M. I } \\
\text { Ann. } \\
\text { Ab. }\end{array}$ & $\begin{array}{l}\text { M. I Imp. } \\
\text { Ab. }\end{array}$ \\
\hline Intercept & -0.001 & 0.001 & -0.035 & $0.086 * *$ \\
\hline M. I intercept coefficient & & -0.014 & 0.136 & 0.097 \\
\hline M. I intercept dummy & -0.396 & & & -0.006 \\
\hline M. I Announcement day Ab. return & 0.005 & -0.000 & -0.060 & -0.069 \\
\hline M. I implementation day Ab. return & 0.007 & -0.000 & -0.157 & \\
\hline M. I Market coefficient & 0.002 & 0.002 & 0.048 & -0.008 \\
\hline M. I Market interaction coefficient & 0.003 & 0.000 & 0.031 & 0.000 \\
\hline M. I SMB coefficient & -0.009 & -0.001 & -0.048 & 0.009 \\
\hline M. I VMG coefficient & 0.000 & 0.001 & -0.031 & 0.015 \\
\hline Market value percentile rank on implementation day & 0.002 & -0.002 & $0.079 *$ & -0.018 \\
\hline Bid ask spread average percentage $t-255$ through $t-6$ & 0.020 & -0.008 & 0.172 & -0.142 \\
\hline Standardised volume, $\mathrm{t}-255$ through $\mathrm{t}-6$ & $0.007 *$ & 0.001 & -0.016 & -0.020 \\
\hline Average free float, $\mathrm{t}-255$ through $\mathrm{t}-6$ & -0.003 & -0.000 & -0.062 & $-0.072 * * *$ \\
\hline Imp. lag in trading days & 0.000 & 0.000 & -0.000 & -0.000 \\
\hline Other information disclosed at time of announcement & -0.003 & 0.001 & -0.007 & -0.022 \\
\hline Placing / capital raising concurrent with migration & -0.003 & -0.000 & -0.011 & 0.002 \\
\hline Shareholders allowed to vote on proposed migration & 0.000 & 0.002 & -0.024 & 0.032 \\
\hline \multicolumn{5}{|l|}{ Stated Motivation for migration, defined in Table 1} \\
\hline Shareholder protection statement (MAIN2AIM only) & -0.007 & 0.000 & -0.039 & $0.008 * *$ \\
\hline Increase investor base & $0.013^{*}$ & 0.000 & -0.006 & 0.036 \\
\hline Improve liquidity / appropriate for current liquidity & -0.012 & -0.001 & 0.026 & 0.002 \\
\hline Raised profile of company or product market & -0.004 & -0.000 & 0.087 & 0.032 \\
\hline Attract staff & -0.019 & -0.000 & -0.079 & -0.017 \\
\hline Growth and/or appropriate for firm's size & -0.002 & -0.000 & -0.001 & -0.002 \\
\hline Cost savings, simplification of reporting / regulation & 0.001 & 0.000 & 0.007 & -0.012 \\
\hline Suitable for existing investor base & $0.022 * * *$ & -0.000 & 0.048 & 0.057 \\
\hline General flexibility regarding corporate transactions & 0.000 & -0.001 & 0.022 & -0.007 \\
\hline Ease of future acquisitions & -0.003 & -0.000 & -0.011 & -0.000 \\
\hline Ease of future capital raising & 0.008 & -0.002 & -0.039 & 0.049 \\
\hline Restructuring/refocusing/refinancing/write-down & -0.008 & 0.001 & -0.040 & 0.013 \\
\hline Tax benefits for investors & 0.005 & 0.001 & -0.005 & -0.005 \\
\hline Violates the minimum $25 \%$ free float rule, or similar & 0.002 & $-0.003 * *$ & $-0.086^{*}$ & -0.002 \\
\hline Adjusted R squared & $-0.5 \%$ & $2.3 \%$ & $1.2 \%$ & $-1.3 \%$ \\
\hline
\end{tabular}

Coefficients for the cross sectional Model II in which dependent variables are the model I coefficients that identify abnormal returns, namely: intercept (Int.); intercept dummy variable representing the change in agency risk premium post implementation; the announcement day abnormal return; and the implementation day abnormal return t. Abbreviations are: model I (M. I), model II (M.II), intercept (Int.) announcement day (Ann.), implementation day (Imp.), abnormal return (Ab.). Dummy variables include: other information disclosed at time of announcement; placing / capital raised at the time of migration; shareholders allowed to vote on proposed migration and; stated motivations for migration as defined in Table 1. The following symbols: $* * *, * *, *$ indicate significance at: $0.01,0.05$ and 0.10 levels respectively. 


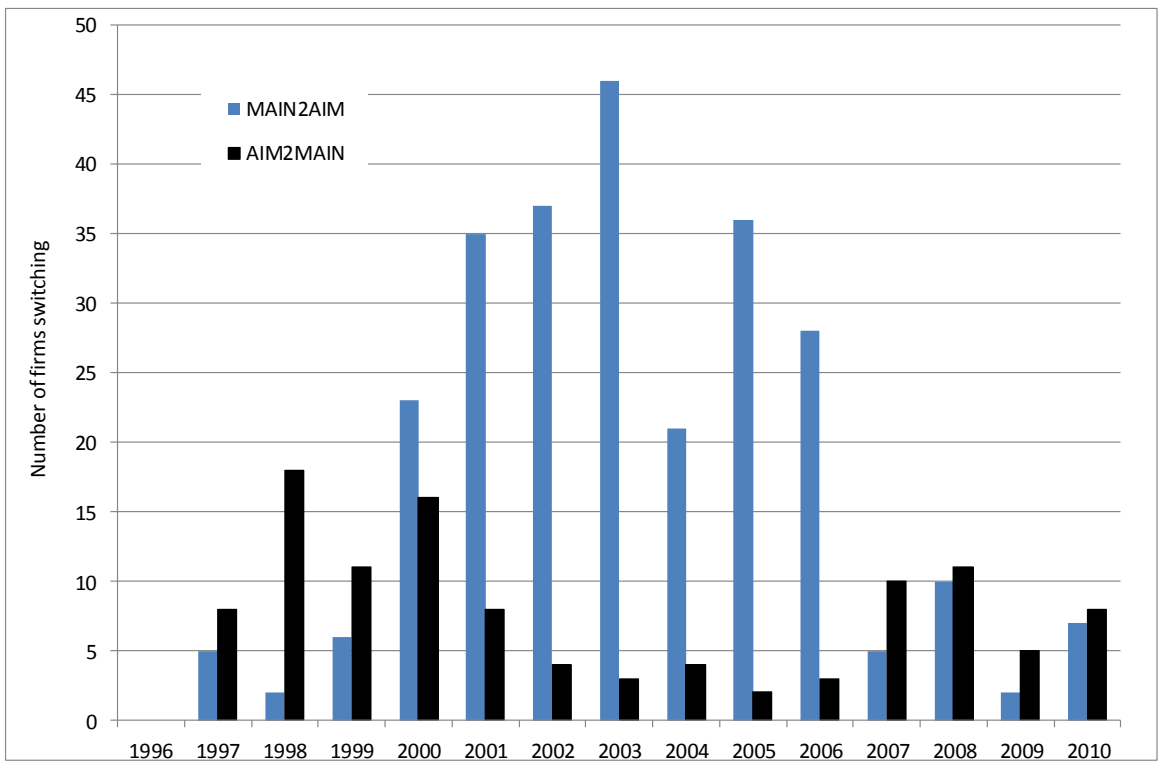

Figure 1

Number of firms migrating in each year of the study period

AIM2MAIN firms are those that transfer from the AIM to the main market. MAIN2AIM firms are those transferring in the opposite direction. Our sample began in 1996 although no firms migrated that year. Source: London Stock Exchange New Issues and IPO Summary (LSE 2011b). 